\title{
Where are the mussels on Cook Strait (New Zealand) shores? Low seston quality as a possible factor limiting multi-species distributions
}

\author{
Jonathan P. A. Gardner* \\ Island Bay Marine Laboratory, School of Biological Sciences, Victoria University of Wellington, PO Box 600, Wellington, \\ New Zealand
}

\begin{abstract}
Examination of the physiological ecology of 3 sympatrically occurring mytilids (the ribbed, blue and greenshell mussels, Aulacomya maoriana, Mytilus galloprovincialis and Perna canaliculus, respectively) was carried out during summer and winter at 2 sites which differ markedly in their environmental characteristics (Mahanga Bay inside Wellington Harbour, where mussels are abundant, and Island Bay on the exposed Cook Strait shore, where mussels are absent). Seston components (particle counts per $\mathrm{ml}$ in the size range 2.5 to $63 \mu \mathrm{m}$, total particulate matter [TPM], particulate organic matter [POM], and percent organic matter [PCOM]) all varied significantly between sites and between seasons. Mahanga Bay seston exhibited characteristics typical of productive temperate coastal waters, whereas Island Bay seston was characterised by low POM and low PCOM values. Weight-standardised clearance rate $\left(C R_{S}\right)$, net absorption efficiency $(A E)$ and Scope for Growth (SFG) values were determined for all 3 mussel species at both sites during both seasons. At Island Bay there was no evidence of seasonal differences in $C_{S}$ whereas at Mahanga Bay species-specific $C_{S}$ values were all highest in the winter. Regardless of season, $\mathrm{CR}_{\mathrm{S}}$ estimates for all 3 species were higher at Mahanga Bay than at Island Bay. At both sites, AE estimates were highest in the winter, and AE estimates were higher at Mahanga Bay than at Island Bay during each season. SFG estimates mirrored AE estimates, with SFG at both sites being highest in winter, and higher at Mahanga Bay than at Island Bay during each season. The SFG data support the hypothesis that mussels are absent from sites along Cook Strait shores because they do not enjoy a positive energy balance for long periods of time, consistent with the low seston organic matter levels at such locations. The SFG data also indicate that mussels inside Wellington Harbour can maintain a large, positive net energy balance throughout the year, consistent with the considerable biomass and very large size of all 3 species in this environment.
\end{abstract}

KEY WORDS: Aulacomya maoriana Mytilus galloprovincialis - Perna canaliculus . Mussels . Ecological distribution - Physiological energetics - Seston · Scope for Growth

\section{INTRODUCTION}

In 1949 the Stephensons published a landmark paper in marine ecology on the universality of patterns of intertidal zonation on temperate rocky shores (Stephenson \& Stephenson 1949). Although the universality of this zonation pattern was quickly repudiated, the basic premise remains: temperate rocky

\footnotetext{
•E-mail: jonathan.gardner@vuw.ac.nz
}

shores are characterised by zones of the same groups of organisms from the top of the intertidal region to the sublittoral (myxophysid lichens, littorinid gastropods, barnacles, mussels, kelps), even though the species and genera in question differ from region to region. Thus, mytilid mussels are characteristic of lower midshore regions worldwide and constitute an obvious and important ecological component of temperate intertidal rocky shore communities. The main reason for the lack of true universality of this phenomenon is that, while the majority of temperate rocky shores con- 
form to this pattern, a small number do not. One example of this is the wave-exposed shoreline of much of the Cook Strait which separates New Zealand's North Island from the South Island. Mussels are mostly or entirely absent from large stretches of this coast, despite apparently suitable substrate being available for colonisation. This is true of large areas of the outer Marlborough Sounds of the South Island, and also of the southern-most coast line of the North Island towards Wellington Harbour (Fig. 1). Wellington Harbour itself exhibits the typical characteristics of intertidal zonation described by the Stephensons, including 4 species of mytilids (the little black mussel Xenostrobus pulex, the blue mussel Mytilus galloprovincialis, the endemic ribbed mussel Aulacomya maoriana, and the endemic greenshell mussel Perna canaliculus) which occur in large and dense beds wherever suitable substrate occurs. Given that mussels are defining members of temperate intertidal rocky shore communities, it is of interest to determine why mussels do not occur on many Cook Strait shores but are so abundant in the neighbouring Wellington Harbour.

J. P. A. Gardner \& R. J. Thompson (unpubl.) investigated the physiological energetics of Perna canaliculus

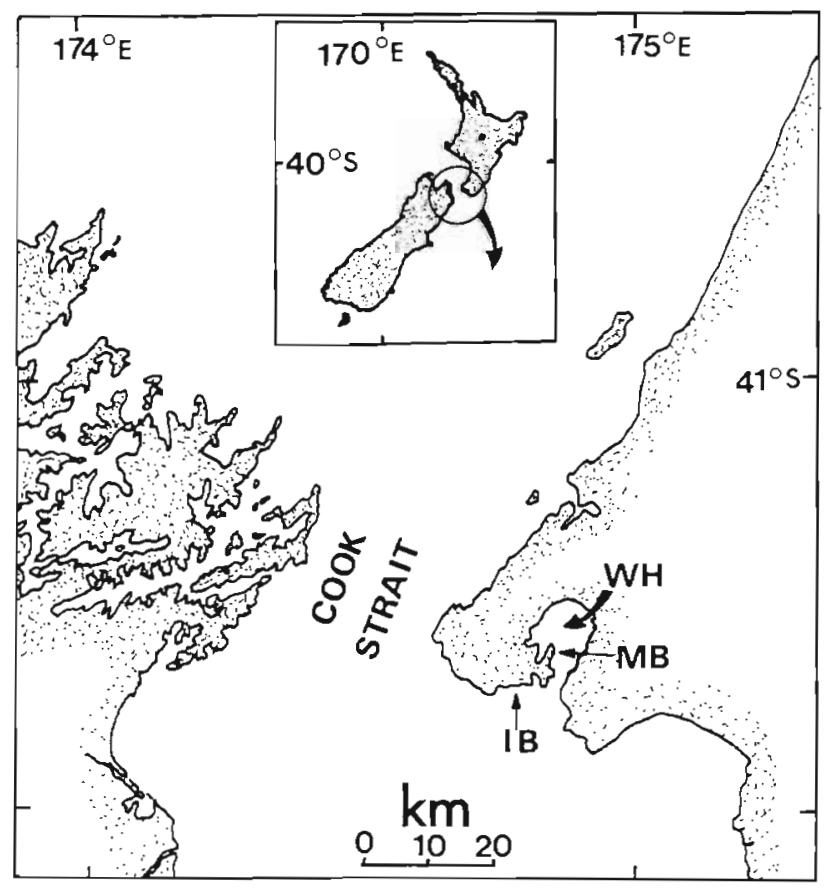

Fig. 1. Geographic location of the experimental sites. Inset map: the North and South Islands of New Zealand with the Cook Strait region circled. Main map: Cook Strait region showing detail of the Marlborough Sounds (northeast end of the South Island) and the 2 experimental sites, IB = Island Bay on the exposed Cook Strait coast and $\mathrm{MB}=$ Mahanga Bay inside $W H=$ Wellington Harbour at Island Bay (a Cook Strait site at which mussels are absent) under ambient late-summer conditions of low seston quality. They reported a mean negative net absorption efficiency (AE) value of $-14.2 \%$ for greenshell mussels fed ambient seston which was characterised by a low organic matter content of $\sim 22 \%$. Consistent with published findings for other mytilid species, principally Mytilus edulis, Gardner \& Thompson (unpubl.) suggested that the combined effects of metabolic faecal loss (MFL) and naturally low levels of seston organic matter content resulted in the negative $\mathrm{AE}$ estimates, which in turn translated into negative Scope for Growth (SFG) estimates. It was concluded that under ambient late-summer conditions mussels were losing energy faster than they were gaining it, a state which, for obvious reasons, cannot be sustained for too long. Gardner \& Thompson (unpubl.) hypothesised that the low quality seston along Cook Strait shores might explain why mussels are absent from much of this coastline. However, it was noted that confirmation for such a conclusion would require the estimation of the net energy balance of more than 1 species of mussel in more than 1 time period.

The present paper describes a series of experiments carried out to compare the physiological energetics and SFG of 3 sympatrically occurring mussel species. The purpose of this research was to determine the importance of seasonal variation in seston quantity (total particulate matter [TPM]) and quality (particulate organic matter [POM], and percent organic matter [PCOM]) as factors explaining the presence or absence of mussels at 2 neighbouring sites which are characterised by contrasting environmental conditions. The experiments were conducted in early summer and mid-winter at Island Bay on the Cook Strait, where mussels are absent, and Mahanga Bay in Wellington Harbour, where mussels are abundant. The findings indicate that highly significant differences exist in natural seston characteristics between the 2 sites, and that such differences effect the SFG of the 3 species in a manner consistent with the presence of mussels at the one site and their absence at the other.

\section{MATERIALS AND METHODS}

Sample collection and holding conditions. Mussels (Aulacomya maoriana, Mytilus galloprovincialis and Perna canaliculus) were collected from the low intertidal region at Seatoun, inside Wellington Harbour, during the early austral summer (26 November 1996), and again during mid-winter (30 June 1997). On both occasions, mussels were cleared of all epibionts: approximately 30 individuals of each species were held for a minimum of $10 \mathrm{~d}$ at the Island Bay Marine 
Laboratory and the same number of each species was transferred to and held for a minimum of $10 \mathrm{~d}$ at NIWA's Aquaculture Facility, Mahanga Bay. Both facilities are representative of their 2 respective systems (harbour and open coast) in terms of the biological community along the shore next to the facilities and in terms of the water supply to each laboratory. A wide size (shell length) range of each species was chosen for the experimental work. Mussels held at Island Bay were provided with unfiltered seawater pumped into the Marine Laboratory from the coastal waters of Cook Strait. Mussels held at Mahanga Bay were provided with unfiltered seawater pumped directly into the facility from Wellington Harbour. Seawater intake pipes at both facilities draw water from $\sim 2 \mathrm{~m}$ below the surface at mean low water (MLW) and from a few metres offshore. At both Island Bay and Mahanga Bay a comparison was made of seawater flowing through the laboratory with seawater in the immediate vicinity of the intake pipe. Although particle counts and estimates of TPM and POM were lower inside the laboratory than in the sea, the magnitude of the differences was small and reflected the settlement of larger particles $(>60 \mu \mathrm{m})$ which do not constitute the main food source of suspension-feeding mussels. The following methodology follows that described by Gardner \& Thompson (unpubl.).

Seston characteristics. During any 24 h experimental period (see subsequent 'Clearance rates' section) three $2 \mathrm{l}$ water samples were taken from the feeding apparatus overflow pipe to determine seston concentrations. Seston was concentrated on to pre-ashed and pre-weighed Whatman GF/C filters. Seston TPM $\left(60^{\circ} \mathrm{C}\right.$ for $24 \mathrm{~h})$ and POM $\left(450^{\circ} \mathrm{C}\right.$ for $\left.24 \mathrm{~h}\right)$ were calculated for each sample to an accuracy of $0.1 \mathrm{mg}$. Seston PCOM= $[(\mathrm{POM} / \mathrm{TPM} \times 100)]$ was also calculated. Seston particle counts in the size range of 2.5 to $63.0 \mu \mathrm{m}$ were taken using a Coulter $\mathrm{Z} 1$ dual threshold electronic particle counter fitted with a $100 \mu \mathrm{m}$ aperture.

Clearance rates (CR: $1 \mathbf{h}^{-1}$ ). Eighteen mussels of each species were used to estimate CR (= volume of water cleared of particles mussel ${ }^{-1} \mathrm{~h}^{-1}$ ) at both sites during both seasons. The experimental set-up and protocol followed Bayne et al. (1976) and Gardner \& Thompson (unpubl.). It consists of a header tank (maintained at constant pressure with an overflow pipe set so that the volume of the header tank was 20 l) which fed simultaneously into each of 13 chambers through 13 individual flow restrictors. Because $C R$ is a function of body size, chamber geometry, and flow rate (Widdows \& Johnson 1988), the flow rate through each chamber was adjusted according to the size of the mussel being tested, and varied between 100 to $500 \mathrm{ml} \mathrm{min}{ }^{-1}$. Outflow from each chamber was via a standpipe at the opposite end of the chamber from the inflow. During any $24 \mathrm{~h}$ experimental period, 6 mussels of 2 separate species, representing a range of different shell lengths, were tested. One mussel was placed in each of 12 chambers while the thirteenth chamber was left empty as a control. The location of the control chamber was varied among experiments, and the flow rate of the control chamber was held at approximately the mean flow rate of the 12 experimental chambers. Mussels were allowed to feed for approximately $1 \mathrm{~h}$ before water samples were taken. Before each period of water sampling from the outflow standpipes of the 12 experimental chambers, mussels were checked to ensure that their valves were open, that their mantle tentacles were extended, and that there was evidence of water movement around them consistent with feeding activity. Timed outflow water samples were collected simultaneously from the standpipes of all 13 chambers on 3 occasions throughout each $24 \mathrm{~h}$ period. Particle counts were made of unfiltered outflow water of each of the 13 chambers using a Coulter Z1 particle counter fitted with a $100 \mu \mathrm{m}$ aperture tube which recorded all particles in the size range 2.5 to $63 \mu \mathrm{m}$. The volume of seawater sampled by the Coulter counter was set at $1 \mathrm{ml}$. Particle counts from experimental chambers were always $>10 \%$ lower than particle counts from the control chamber. CR for each mussel at each time of sampling was calculated as number of particles removed from the water per unit volume by reference to particle levels in the control sample. Mean CR per mussel per $24 \mathrm{~h}$ period was calculated and this figure was employed for statistical analyses. At the end of each $24 \mathrm{~h}$ experimental period the mussels were shucked, and dried $\left(60^{\circ} \mathrm{C}\right.$ for 24 to $\left.48 \mathrm{~h}\right)$ and dry body weights were measured to an accuracy of $0.1 \mathrm{mg}$. CR was standardized to mass-specific rates for mussels of $1 \mathrm{~g}$ dry weight. Weight exponents $(b$ in the allometric equation $Y=a X^{b}$, where $Y^{r}$ is the physiological rate process, $X$ is the dry body weight, and $a$ and $b$ are fitted parameters) were determined from log-log plots of CR as a function of dry body weight.

Net absorption efficiency (AE). During each $24 \mathrm{~h}$ $\mathrm{CR}$ experiment a subsample of faecal material was collected from each of the 12 chambers containing a mussel using a pipette and without disturbing the feeding mussels. The faecal sample was concentrated onto pre-ashed and pre-weighed Whatman GF/C filters for dry weight (dried for $24 \mathrm{~h}$ at $60^{\circ} \mathrm{C}$ ) and ashfree dry weight (AFDW - weight loss on ignition at $450^{\circ} \mathrm{C}$ after $24 \mathrm{~h}$ ) determinations. No pseudofaecal material was produced by mussels held at Island Bay. Pseudofaecal material was collected from mussels held at Mahanga Bay, but these samples were lost when the freezer in which they were held broke down. AE estimates for mussels from Island Bay are therefore calculated from ingestion of non-enriched 
seston because no pseudofaeces were produced, whereas AE estimates for mussels from Mahanga Bay were calculated for an enriched diet following selection against those seston particles rejected as pseudofaeces. Individual net AE values were calculated for all mussels used in the CR experiments according to Conover (1966):

$$
\mathrm{AE}=(\mathrm{F}-\mathrm{E}) /[(1-\mathrm{E}) \mathrm{F}]
$$

where $\mathrm{F}=\mathrm{AFDW}$ to dry weight ratio of seston supplied to mussels, and $E=A F D W$ to dry weight ratio of mussel faeces. Individual AE values were not weightstandardised because variation in AE was independent of dry body weight for all 3 species.

Scope for Growth (SFG: $\mathbf{J ~ g}^{-1} \mathbf{h}^{-1}$ ). SFG was calculated from the above physiological measurements according to Widdows (1985) and Gardner \& Thompson (unpubl.). Because ammonia excretion was not measured, the estimates of SFG will be slightly elevated. Species-specific estimates of oxygen consumption rate $\left(\mathrm{VO}_{2}\right)$ were obtained from published values: values employed were $0.17,0.40$ and $0.45 \mathrm{ml} \mathrm{O}_{2} \mathrm{~g}^{-1} \mathrm{~h}^{-1}$ for Aulacomya maoriana, Mytilus galloprovincialis and Perna canaliculus, respectively (Griffiths \& King [1979] for Aulacomya ater, Labarta et al. [1997] for M. galloprovincialis, Gardner \& Thompson [1999] for P. canaliculus) and are consistent with unpublished data for these species at these sites (J. G. Helson \& J. P. A. Gardner unpubl.). Natural variability in $\mathrm{VO}_{2}$ values, for example as associated with seasonal physiological condition or the rate of organic absorption, does not ultimately effect the net energy balance of any of the 3 species. All data were standardised to $1 \mathrm{~g}$ dry body weight equivalents. Oxygen consumption was converted to energy equivalents according to Gnaiger (1983) such that $1 \mathrm{ml} \mathrm{O} 2=20.08 \mathrm{~J}$. POM was converted to energy equivalents according to Crisp (1971) such that $1 \mathrm{mg} P O M=20.78 \mathrm{~J}$. SFG was calculated from the balanced energy equation (without the ammonium excretion term) as follows:

$$
C=P+R+F
$$

where $C=$ total energy consumed, $P=$ production of somatic and reproductive tissues, $R=$ respiratory energy loss, and $F=$ faecal energy loss. Because the absorbed ration $(A)$ is the product of $C$ and $A E, P$ can be expressed as

$$
P=A-R
$$

$P$ is therefore the difference between energy absorbed from the food and energy expenditure due to respiration and excretion. Calculation of $C, A$ and $R$ (all in $\mathrm{J} \mathrm{g}^{-1} \mathrm{~h}^{-1}$ ) follows Widdows \& Johnson (1988, p. 116):

$$
\begin{gathered}
C=\mathrm{CR}\left(\mathrm{l} \mathrm{g}^{-1} \mathrm{~h}^{-1}\right) \times \mathrm{POM}\left(\mathrm{mg} \mathrm{l}^{-1}\right) \times 23 \mathrm{~J} \mathrm{mg}^{-1} \text { AFDW } \\
A=C \times \mathrm{AE} \\
R=\mathrm{VO}_{2}\left(\mathrm{ml} \mathrm{O} \mathrm{g}^{-1} \mathrm{~h}^{-1}\right) \times 20.33 \mathrm{~J} \mathrm{ml}^{-1} \mathrm{O}_{2}
\end{gathered}
$$

$P$ is referred to as Scope for Growth (SFG) and reflects the overall energy balance of the individual mussel. Because there was no observed pseudofaecal production by mussels held at Island Bay, the calculated SFG values represent estimates of energy gain or loss without consideration of particle selection and loss off the gill, i.e., $C R=$ ingestion rate (IR). However, because pseudofaecal samples were not available for the Mahanga Bay mussels, the SFG values for these mussels are overestimates. Positive SFG values reflect energy which is available for production (somatic and/or reproductive growth) after routine metabolic demands have been met, whereas negative SFG values reflect an overall loss of energy by the individual.

Statistical analyses. Non-parametric ranked ANOVA was carried out to test for the effects of site and season upon the 3 separate dependent variables which define seston quantity and quality, namely TPM, POM and PCOM. Data were not normally distributed (Shapiro-Wilks statistic of Proc Univariate; SAS 1987), so were rank transformed before non-parametric analysis (Conover \& Iman 1981). The 2 single effect terms (site and season) and their interaction were tested in each ANOVA model: non-significant terms were dropped from the analysis because they did not explain significant variation in the dependent variable.

ANOVA was employed to test for effects of the independent variables (species, site and season) and all possible interaction terms upon each separate physiological dependent variable $\left(\mathrm{CR}_{\mathrm{S}}, \mathrm{AE}, \mathrm{SFG}\right)$. Non-significant terms were dropped from the ANOVA model until only single terms and interactions which explained significant variation in the dependent variable remained in the model. Analyses of $C_{S}, A E$ and $S F G$ were carried out by non-parametric ranked ANOVA (Conover \& Iman 1981) because the data were not normally distributed, even after transformation (ShapiroWilks statistic of Proc Univariate; SAS 1987).

\section{RESULTS}

\section{Seston characteristics}

Data for TPM, POM, PCOM and particle counts are presented in Table 1. TPM concentrations were lowest at Island Bay in the summer and highest at Island Bay in the winter (ANOVA: $\mathrm{R}^{2}=0.397, \mathrm{p}<0.0001$; site: $\mathrm{p}=$ 
Table 1 . Seston and water characteristics, including temperature $\left({ }^{\circ} \mathrm{C}\right)$, total particulate matter (TPM), particulate organic matter (POM), percent organic matter (PCOM), and particle counts [mean $\pm \mathrm{SD}(\mathrm{n})]$

\begin{tabular}{|c|c|c|c|c|c|c|}
\hline Site & Season & $\begin{array}{c}\text { Temperature } \\
\left({ }^{\circ} \mathrm{C}\right)\end{array}$ & TPM & POM & PCOM & $\begin{array}{l}\text { No. of particles } \\
\text { in range } \\
2.5-63.0 \mu \mathrm{ml}^{-1}\end{array}$ \\
\hline Island Bay & Summer & $\begin{array}{c}15.8 \\
\pm 0.49 \\
(15)\end{array}$ & $\begin{array}{c}9.3 \\
\pm 3.0 \\
(30)\end{array}$ & $\begin{array}{c}2.8 \\
\pm 0.9 \\
(30)\end{array}$ & $\begin{array}{l}30.07 \\
\pm 2.31 \\
(30)\end{array}$ & $\begin{array}{c}8013.9 \\
\pm 2733.0 \\
(31)\end{array}$ \\
\hline Island Bay & Winter & $\begin{array}{c}10.8 \\
\pm 0.27 \\
(15)\end{array}$ & $\begin{array}{l}14.0 \\
\pm 2.4 \\
(15)\end{array}$ & $\begin{array}{l}3.0 \\
\pm 0.7 \\
(15)\end{array}$ & $\begin{array}{c}21.45 \\
\pm 2.66 \\
(15)\end{array}$ & $\begin{array}{c}25958.4 \\
\pm 13919.2 \\
(45)\end{array}$ \\
\hline Mahanga Bay & Summer & $\begin{array}{c}15.9 \\
\pm 0.32 \\
(15)\end{array}$ & $\begin{array}{l}13.7 \\
\pm 3.5 \\
(30)\end{array}$ & $\begin{array}{c}4.0 \\
\pm 1.1 \\
(30)\end{array}$ & $\begin{array}{l}28.92 \\
\pm 1.51 \\
(30)\end{array}$ & $\begin{array}{c}24109.5 \\
\pm 6130.8 \\
(40)\end{array}$ \\
\hline Mahanga Bay & Winter & $\begin{array}{c}10.4 \\
\pm 0.31 \\
(15)\end{array}$ & $\begin{array}{l}11.8 \\
\pm 1.3 \\
(15)\end{array}$ & $\begin{array}{l}7.0 \\
\pm 1.1 \\
(15)\end{array}$ & $\begin{array}{c}59.17 \\
\pm 6.44 \\
(15)\end{array}$ & $\begin{array}{c}20246.9 \\
\pm 5109.9 \\
(49)\end{array}$ \\
\hline
\end{tabular}

0.0168 ; season $\times$ site: $\mathrm{p}<0.0001$ ). At both sites, POM concentrations increased from summer to winter, by $-7 \%$ at Island Bay and by $75 \%$ at Mahanga Bay (ANOVA: $\mathrm{R}^{2}=$ 0.690; $p<0.0001$; site: $p<0.0001$; season: $p<0.0001$; site $\times$ season: $p<0.0001)$. POM concentrations were higher at Mahanga Bay than at Island Bay, regardless of season. PCOM decreased from summer to winter by almost $30 \%$ at Island Bay, but more than doubled at Mahanga Bay (ANOVA: $R^{2}=0.910 ; p<0.0001$; site: $p<0.0001$; season $\times$ site: $p<0.0001$ ). During the summer the PCOM values at both sites were similar at $-30 \%$, but during the winter the value was almost 3 times higher at Mahanga Bay than at Island Bay ( 60 vs $21 \%$ ). The number of particles in the range 2.5 to $63.0 \mu \mathrm{m}$ increased from summer to winter by more than 3-fold at Island Bay but decreased by $\sim 16 \%$ at Mahanga Bay, mirroring the changes observed in TPM concentrations.

\section{Clearance rates (CR)}

$\mathrm{CR}_{\mathrm{S}}$ values $\left(\mathrm{l} \mathrm{g}^{-1} \mathrm{~h}^{-1}\right)$ are presented in Table 2. Typically, Aulacomya maoriana exhibited the lowest, and Perna canaliculus the highest, $\mathrm{CR}_{\mathrm{S}}$ values regardless of site or season. At Island Bay, season had no apparent effect upon $C R_{S}$ for any of the 3 species, whereas $C R_{S}$ values at Mahanga Bay were all higher in the winter than in the summer. $C_{S}$ values for all species were higher at Mahanga Bay than at Island Bay regardless of season. ANOVA of $\mathrm{CR}_{\mathrm{S}}$ values (Table 3 ) indicated that a model including 3 single effects and 2 interaction terms explained significant variation in $\mathrm{CR}_{\mathrm{S}}$ $\left(R^{2}=0.524, p<0.0001\right)$. Because significant interactions existed among terms it was not possible to determine the significance of the single-term-dependent variables.

Table 2. Values for clearance rate (CR in $\mathrm{l} \mathrm{g}^{-1} \mathrm{~h}^{-1}$ ) and absorption efficiency (AE) for Aulacomya maoriana, Mytilus galloprovincialis, and Perna canaliculus at both sites during both seasons

\begin{tabular}{|lllcl|}
\hline Species & Season & Site & CR (mean \pm SD) & AE (mean \pm SD) \\
\hline A. maoriana & Summer & Island Bay & $1.73 \pm 0.78$ & $0.0049 \pm 0.2344$ \\
M. galloprovincialis & Summer & Island Bay & $2.82 \pm 0.97$ & $0.0348 \pm 0.1127$ \\
P. canaliculus & Summer & Island Bay & $3.40 \pm 1.12$ & $0.0736 \pm 0.1370$ \\
A. maoriana & Winter & Island Bay & $1.73 \pm 0.55$ & $0.3406 \pm 0.1915$ \\
M. galloprovincialis & Winter & Island Bay & $2.83 \pm 0.93$ & $0.0334 \pm 0.2348$ \\
P. canaliculus & Winter & Island Bay & $3.40 \pm 0.97$ & $0.1967 \pm 0.2945$ \\
A. maoriana & Summer & Mahanga Bay & $1.82 \pm 0.79$ & $0.2368 \pm 0.0851$ \\
M. galloprovincialis & Summer & Mahanga Bay & $3.58 \pm 1.16$ & $0.2702 \pm 0.0968$ \\
P. canaliculus & Summer & Mahanga Bay & $3.51 \pm 1.32$ & $0.3300 \pm 0.1402$ \\
A. maoriana & Winter & Mahanga Bay & $2.55 \pm 0.92$ & $0.8143 \pm 0.0631$ \\
M. galloprovincialis & Winter & Mahanga Bay & $4.49 \pm 0.76$ & $0.7920 \pm 0.0368$ \\
$P$. canaliculus & Winter & Mahanga Bay & $4.61 \pm 1.18$ & $0.8013 \pm 0.0665$ \\
\hline
\end{tabular}


Table 3. ANOVA testing for the effects of season, site, species and their interactions upon ranked standardised clearance rate $\left(\mathrm{CR}_{\mathrm{S}}\right.$ in $\left.\mathrm{lg}^{-1} \mathrm{~h}^{-1}\right)$

\begin{tabular}{|c|c|c|c|c|c|}
\hline Source & df & SS & MS & $F$-value & $\mathrm{p}$ \\
\hline Model & 7 & 439781.3 & 62825.9 & 32.67 & 0.0001 \\
\hline Error & 208 & 400008.7 & 1923.1 & & \\
\hline Corrected total & 215 & 839790.0 & & & \\
\hline Season & 1 & 23437.5 & 23437.5 & 12.2 & 0.0006 \\
\hline Site & 1 & 61273.4 & 61273.4 & 31.9 & 0.0001 \\
\hline Species & 2. & 318090.1 & 159049.0 & 82.7 & 0.0001 \\
\hline Site $\times$ Species & 2 & 13409.7 & 6704.9 & 3.5 & 0.0324 \\
\hline Season $\times$ Site & 1 & 23562.7 & 23562.7 & 12.3 & 0.0006 \\
\hline
\end{tabular}

\section{Net absorption efficiency (AE)}

Mean net $\mathrm{AE}$ values are presented in Table 2: these values reflect non-enriched (i.e., no pseudofaecal production) and enriched (i.e., pseudofaecal production) seston ingestion at Island Bay and Mahanga Bay, respectively. These data indicate that (1) AE estimates during the summer at Island Bay were positive but low; (2) during the winter at Island Bay AE estimates for Aulacomya maoriana and Perna canaliculus were moderately high, but the AE for Mytilus galloprovincialis remained low and positive; (3) during the summer at Mahanga Bay $\mathrm{AE}$ estimates were in the range of 20 to $33 \%$; and (4) during the winter at Mahanga Bay all AE estimates were high $(-80 \%)$ with low standard deviations. The significant ANOVA model $\left(\mathrm{R}^{2}=0.717, \mathrm{p}<0.0001\right)$ indicated that season, site, species and all three 2-way interactions explained significant variation in $\mathrm{AE}$ (Table 4). Mean AE values were higher in winter than in summer, were higher at Mahanga Bay than at Island Bay, and were higher in both $A$. maoriana and $P$. canaliculus than in $M$. galloprovincialis. However, significant interaction terms precluded the identification of significant single term effects.

\section{Scope for Growth (SFG)}

Energy consumed $\left(C, \mathrm{~J} \mathrm{~h}^{-1}\right)$, energy absorbed $(A$, $\left.\mathrm{J} \mathrm{h}^{-1}\right)$, energy respired $\left(R, \mathrm{~J} \mathrm{~g}^{-1} \mathrm{~h}^{-1}\right)$ and SFG $\left(\mathrm{J} \mathrm{g}^{-1} \mathrm{~h}^{-1}\right)$ estimates are presented in Table 5 . All 3 species exhibited negative SFG estimates under the summer conditions at Island Bay. During the winter at Island Bay, SFG values for Aulacomya maoriana and Perna canaliculus were moderately high, whereas those for Mytilus galloprovincialis were negative. At Mahanga Bay during the summer SFG values for all 3 species were positive and ranged from 34 to $121 \mathrm{~J} \mathrm{~g}^{-1} \mathrm{~h}^{-1}$. During the winter at Mahanga Bay the SFG estimates for all 3 species were very high, ranging from 333 to $614 \mathrm{~J} \mathrm{~g}^{-1} \mathrm{~h}^{-1}$. ANOVA of SFG values (Table 6) indicated that the 3 single dependent variables and all 2-way interaction terms had a significant effect upon SFG $\left(R^{2}=0.777, p<0.0001\right)$. Mean $S F G$ values were higher at Mahanga Bay than at Island Bay, were higher in the winter than in the summer, and were highest in $P$. canaliculus and lowest in $A$. maoriana. Significant interaction terms, however, precluded the identification of significant dependent variables. As previously indicated, it is important to appreciate that the SFG estimates obtained for mussels from Mahanga

Table 4. ANOVA testing for the effects of season, site, species and their interactions upon ranked absorption efficiency, AE

\begin{tabular}{|c|c|c|c|c|c|}
\hline Source & $\mathrm{df}$ & SS & MS & $F$-value & $\mathrm{p}$ \\
\hline Model & 9 & 593514.5 & 65946.1 & 57.61 & 0.0001 \\
\hline Error & 205 & 234665.0 & 1144.7 & & \\
\hline Corrected total & 214 & 828179.5 & & & \\
\hline Species & 2 & 347569.0 & 347569.0 & 303.6 & 0.0001 \\
\hline Season & 1 & 185099.3 & 185099.3 & 161.7 & 0.0001 \\
\hline Site & 1 & 10031.1 & 5015.6 & 4.4 & 0.0137 \\
\hline Season $\times$ Site & 1 & 24917.6 & 24917.6 & 21.8 & 0.0001 \\
\hline Season $\times$ Species & 2 & 16791.3 & 8395.7 & 7.3 & 0.0008 \\
\hline Site $\times$ Species & 2 & 8266.7 & 4133.3 & 3.6 & 0.0288 \\
\hline
\end{tabular}


Table 5. Components of the energy budget (means $\pm \mathrm{SD}$ ) and Scope for Growth for Aulacomya maoriana, Mytilus galloprovincialis, and Perna canaliculus at 2 sites during 2 seasons

\begin{tabular}{|c|c|c|c|c|c|c|}
\hline Species & Site & Season & $\begin{array}{c}\text { Energy } \\
\text { consumed, } C \\
\left(\mathrm{~J} \mathrm{~g}^{-1} \mathrm{~h}^{-1}\right)\end{array}$ & $\begin{array}{c}\text { Energy } \\
\text { absorbed, } A \\
\left(\mathrm{~J} \mathrm{~g}^{-1} \mathrm{~h}^{-1}\right)\end{array}$ & $\begin{array}{l}\text { Energy } \\
\text { respired } R^{a} \\
\left(\mathrm{~J} \mathrm{~g}^{-1} \mathrm{~h}^{-1}\right)\end{array}$ & $\begin{array}{c}\text { Scope for } \\
\text { Growth } \\
\left(\mathrm{J} \mathrm{g}^{-1} \mathrm{~h}^{-1}\right\}\end{array}$ \\
\hline A. maoriana & Island Bay & Summer & $136.9 \pm 79.7$ & $-1.2 \pm 36.9$ & 3.5 & $-4.7 \pm 36.9$ \\
\hline M. galloprovincialis & Island Bay & Summer & $195.7 \pm 109.2$ & $3.2 \pm 25.2$ & 8.1 & $-4.9 \pm 25.2$ \\
\hline P. canaliculus & Island Bay & Summer & $218.5 \pm 107.7$ & $7.9 \pm 28.5$ & 9.1 & $-1.3 \pm 28.5$ \\
\hline A. maoriana & Island Bay & Winter & $127.8 \pm 39.4$ & $41.7 \pm 24.4$ & 3.5 & $38.2 \pm 24.4$ \\
\hline M. galloprovincialis & Island Bay & Winter & $176.4 \pm 69.2$ & $5.4 \pm 47.1$ & 8.1 & $-27 \pm 47.1$ \\
\hline P. canaliculus & Island Bay & Winter & $21.5 .8 \pm 83.3$ & $34.0 \pm 69.4$ & 9.1 & $24.9 \pm 69.4$ \\
\hline A. maoriana & Mahanga Bay & Summer & $158.3 \pm 70.7$ & $37.6 \pm 19.7$ & 3.5 & $34.2 \pm 19.7$ \\
\hline M. galloprovincialis & Mahanga Bay & Summer & $361.6 \pm 154.8$ & $95.5 \pm 47.2$ & 8.1 & $87.4 \pm 47.2$ \\
\hline P. canaliculus & Mahanga Bay & Summer & $353.6 \pm 182.4$ & $129.8 \pm 93.7$ & 9.1 & $120.6 \pm 93.7$ \\
\hline A. maoriana & Mahanga Bay & Winter & $417.2 \pm 160.3$ & $336.9 \pm 123.5$ & 3.5 & $333.5 \pm 123.5$ \\
\hline M. galloprovincialis & Mahanga Bay & Winter & $735.7 \pm 119.0$ & $582.9 \pm 97.5$ & 8.1 & $574.8 \pm 97.5$ \\
\hline P. canaliculus & Mahanga Bay & Winter & $778.4 \pm 188.7$ & $622.7 \pm 162.1$ & 9.1 & $613.5 \pm 162.1$ \\
\hline
\end{tabular}

Table 6. ANOVA testing for the effects of season, site, species and their interactions upon Scope for Growth (SFG)

\begin{tabular}{|c|c|c|c|c|c|}
\hline Source & $\mathrm{df}$ & SS & MS & F-value & p \\
\hline Model & 9 & 643568.9 & 71507.7 & 79.41 & 0.0001 \\
\hline Error & 205 & 184611.1 & 900.5 & & \\
\hline Corrected total & 214 & 828180.0 & & & \\
\hline Site & 1 & 446164.5 & 446164.5 & 495.4 & 0.0001 \\
\hline Season & 1 & 143623.4 & 143623.4 & 159.5 & 0.0001 \\
\hline Species & 2 & 5998.1 & 2999.1 & 3.3 & 0.0377 \\
\hline Site $\times$ Species & 2 & 22891.9 & 11445.9 & 12.7 & 0.0001 \\
\hline Season $\times$ Species & 2 & 7071.4 & 3535.7 & 3.9 & 0.0212 \\
\hline Season $\times$ Site & 1 & 16890.6 & 16890.6 & 18.8 & 0.0001 \\
\hline
\end{tabular}

Bay are overestimates because the calculations are based on the assumption that $\mathrm{CR}=\mathrm{IR}$, an unrealistic assumption which cannot be corrected for because pseudofaecal samples were lost when a freezer broke down. The SFG estimates for mussels held at Island Bay are correct because no pseudofaecal material was produced, thus $C R=I R$.

\section{DISCUSSION}

Gardner \& Thompson (unpubl.) suggested that mussels are absent from Island Bay and other such sites along Cook Strait as a consequence of energy limitation, resulting from low seston quality. If this hypothesis is true then 2 main conditions must be satisfied. First, water column comparisons between the Cook Strait region and Wellington Harbour must be consis- tent with the hypothesis, and second, the physiological responses of the mussels in the 2 contrasting environments must support the hypothesis.

The observed differences in seston quantity and quality between the 2 sites must be explicable in terms of local hydrographic conditions if site-specific differences in seston quality do influence mussel presence or absence. Several authors have suggested that Wellington Harbour is at Ieast partially isolated from the shelf area immediately outside the harbour entrance (Maxwell 1956, Booth 1975, Harris 1990). The Harbour is a sheltered, well-mixed, nutrient-rich, semi-enclosed body of water $\left(85 \mathrm{~km}^{2}\right.$ in area) with a flushing time of $\sim 9$ d (Maxwell 1956, Brodie 1958, Booth 1975, Heath 1977). By comparison, the south coast shelf system (Cook Strait) is a high-energy, very exposed coastline. Strong surface current movement through Cook Strait (primarily the D'Urville Current) 
results in a net flow of oceanic Tasman Sea water down the east coast of the North Island, through Cook Strait, and along Wellington's south coast (Bowman et al. 1983, Harris 1990). This water is generally of low productivity (Bowman et al. 1983) and does not receive significant input of either particulate material (detritus) or dissolved nutrients from riparian flow along this coast (author's pers. obs.). The net result is that primary productivity of the coastal water column is low along Wellington's south coast. Seston quantity (expressed as TPM levels) at both sites during both seasons was moderately high and is not considered to be limiting to mussel growth simply in terms of concentration (Bayne \& Widdows 1978, Widdows et al. 1979). When compared with published values from similar environments, seston quality (expressed as PCOM) was very low at Island Bay during the winter, was moderate at both sites during the summer, and was high at Mahanga Bay during the winter. These seston data are consistent with those of Gardner \& Thompson (unpubl.), who observed that ambient TPM levels at Island Bay during late summer in 1996 were in the range of published values, but that ambient PCOM levels were low compared with published values for other temperate rocky reef sites. The water column conditions of the 2 contrasting regions are therefore consistent with the hypothesis that mussels are absent from large stretches of Cook Strait because they cannot maintain a positive energy balance when feeding on low quality seston. However, other possible biological and physical explanations for the absence of mussels from Cook Strait shores, such as reduced or absent larval supply, harsh environmental conditions, predation, etc., are also presently being investigated.

If mussels are absent from Cook Strait shores as a consequence of low seston quality then the suite of physiological responses of all 3 mussel species should reflect this under experimental conditions at both sites and during both seasons. CR is the most important component of energy acquisition, often accounting for $-70 \%$ of total energy intake (Bayne et al. 1976). In all 3 species $\mathrm{CR}_{5}$ was strongly influenced by seston quality with species-specific $\mathrm{CR}_{\mathrm{S}}$ estimates being higher at Mahanga Bay than at Island Bay in all cases. The higher species-specific $\mathrm{CR}_{\mathbb{S}}$ values at Mahanga Bay than at Island Bay are reflected in the higher values of energy consumed at the former site compared with the latter, and are consistent with the hypothesis being tested.

AE values are most often calculated to reflect the ratio of organic matter in the seston to that in the faeces. However, in the present study, site-specific differences in $\mathrm{AE}$ are confounded to some small extent by the dietary enrichment resulting from pseudofaecal production at Mahanga Bay and the abserice of such at
Island Bay. Regardless of this, bivalve AE is strongly dependent upon food quality (Bricelj \& Malouf 1984, Bayne et al. 1987, Navarro et al. 1991, Gardner \& Thompson unpubl.), in particular, upon the ratio of organic to inorganic matter (Griffiths 1980, Bayne et al. 1987 ). Net AE values typically range from about $-60 \%$ up to about $60 \%$ (Bayne \& Hawkins 1990). Gardner \& Thompson (unpubl.) reported negative net AE values for Perna canaliculus feeding on ambient seston in late summer at Island Bay, a finding which was interpreted in terms of MFL. In the present study the AE values observed for all 3 species at Island Bay during both seasons (0 to $7 \%$ in early summer, 3 to $34 \%$ in winter), and at Mahanga Bay during the summer (23 to $33 \%$ ), are typical of published values, but the $\mathrm{AE}$ values observed for all 3 species at Mahanga Bay during the winter are unusually high (79 to $81 \%$ ). The extent of dietary enrichment by mussels at Mahanga Bay cannot at present be estimated, but the fact that this difference in dietary enrichment exists between the 2 sites highlights the magnitude of the difference in seston quality between them. The AE data for mussels at Island Bay from early summer (Gardner \& Thompson unpubl.) and late summer (present study) indicate that all 3 species are barely able to maintain a positive net AE level, which is a requirement if individuals are to enjoy a positive net energy balance.

SFG represents the net energy balance of an individual after energy acquisition and expenditure have been accounted for. Positive SFG values are good predictors of growth potential (Dame 1976, Bayne \& Worrall 1980, Bayne \& Newell 1983). Negative SFG values usually result because respiratory costs exceed energy absorption, but under certain circumstances SFG can be negative as a result of negative AE values, which can result from MFL (Hawkins \& Bayne 1985, 1992, Bayne \& Hawkins 1990, Gardner \& Thompson unpubl.). SFG is largely independent of temperature within the normal temperature range of the species concerned (Widdows \& Bayne 1971, Bayne et al. 1973, Widdows 1978), i.e., SFG is thought to be regulated in intertidal and shallow subtidal species except at temperature extremes. Thus, temperature differences between seasons within a site, or between sites are unlikely to have contributed to differences in SFG between seasons or between sites because the experiments were carried out under ambient conditions.

SFG estimates for the 3 species were generally of a similar magnitude to each other, and tended to mirror the net AE estimates. Under ambient early summer conditions at Island Bay, all 3 species were losing energy at roughly equal rates. Energy loss continued for Mytilus galloprovincialis at İsland Bay under winter conditions, but the 2 other species both had positive energy balances, typical of values observed in natural 
conditions (Widdows \& Johnson 1988). Gardner \& Thompson (unpubl.) calculated negative SFG values for Perna canaliculus under ambient late summer conditions at Island Bay $\left(-18.6 \mathrm{~J} \mathrm{~g}^{-1} \mathrm{~h}^{-1}\right)$, indicating that these mussels were, in effect, losing more energy than they were acquiring under these conditions. All 3 species of mussels held at Island Bay under ambient early summer conditions in the present study were losing energy faster than they could acquire it. Additionally, because energy loss as a consequence of ammonium excretion was not measured in the present study, these values are all underestimates of the true net energy balance of each species. Thus, during ambient summer conditions and regardless of species, mussels are in a state of negative energy balance at Island Bay. This in itself does not explain why mussels are absent from many Cook Strait shores, because the duration of time that each species can exist for under such conditions depends to a large extent on how much of an energy reserve can be accumulated during winter conditions, and how efficiently such a reserve can be utilised. For Aulacomya maoriana and P. canaliculus at Island Bay, ambient winter conditions resulted in a net positive energy balance, with the opportunity to accumulate energy reserves. For these 2 species, the extent of the net energy loss during summer and the net energy gain during winter will be very much dependent upon the duration of the seston conditions associated with these seasons. For $M$. galloprovincialis, however, a negative net energy balance during winter at Island Bay suggests that this species cannot accumulate energy reserves during winter which might be used to offset energy loss at other times of the year. The main reason for the species-specific difference in $\mathrm{AE}$ and SFG is attributable to a difference in energy absorbed. For all 3 species at Island Bay, energy consumed is very similar in summer and winter, but energy absorbed changes substantially between the 2 seasons. For $A$. maoriana and $P$. canaliculus the estimated energy absorbed increases from a range of -1.2 to $+7.9 \mathrm{~J} \mathrm{~h}^{-1}$ to a range of 34.0 to $41.7 \mathrm{~J} \mathrm{~h}^{-1}$; for $M$. galloprovincialis, the energy absorbed decreases from 3.2 to $0.2 \mathrm{~J} \mathrm{~h}^{-1}$. The reason for this differential response is unknown and warrants further investigation.

For mussels from Mahanga Bay, the SFG values are overestimates of net energy balance because the calculations make no allowance for energy not ingested but lost as pseudofaeces. However, even allowing for pseudofaecal energy loss levels of $50 \%$, which is consistent with values reported for other mytilids under similar circumstances, the SFG values are all high and indicative of an environment which is well suited to mussel growth. With such high SFG estimates it is clear that the major source of energy loss, namely respiration, can vary quite substantially without influencing to any great extent the net energy balance of mussels at Mahanga Bay regardless of season. Thus, although the energy loss associated with respiration is an important component of the overall energy budget of each species, it is energy consumption (the product of CR and POM) and energy absorption (the product of energy consumption and AE) which most significantly effect species-specific SFG estimates under the environmental conditions examined in Wellington Harbour.

In their extensive review of molluscan physiology Bayne \& Newell (1983, p. 487) note that 'It is probably a commonplace for many bivalve species to be limited in their distribution by seasonally varying conditions that lead to periods of negative growth efficiency. However, there are very few published reports of food limitation resulting in the absence of mussels from large stretches of otherwise suitable coast. In this context, the high SFG values obtained for all 3 species at Mahanga Bay contrast sharply with the low values obtained for mussels at Island Bay. Under ambient summer conditions at Mahanga Bay, all 3 species maintained a positive and moderately high energy balance, even allowing for the fact that the energetic costs of ammonium excretion have not been taken into consideration. Under ambient winter conditions, the SFG values for all 3 species increased substantially. These positive SFG values for the Mahanga Bay site are reflected in the dense intertidal and shallow subtidal beds of mixed mussel species, and the large sizes that all 3 species can attain in the Harbour $(\sim 7,9$ and $20 \mathrm{~cm}$ for Aulacomya maoriana, Mytilus galloprovincialis and Perna canaliculus, respectively: author's pers. obs.). Under ambient early summer conditions at Island Bay, all 3 species exhibited negative SFG values, consistent with findings for $P$. canaliculus under late summer ambient conditions at Island Bay (Gardner \& Thompson unpubl.). By mid-winter, the SFG estimates for $A$ maoriana and $P$. canaliculus were positive and moderately high, indicating a period of net energy acquisition. The SFG estimate for $M$. galloprovincialis was negative, however, indicating a prolonged period of net energy loss. Thus, the SFG estimates are consistent with the hypothesis that mussels are absent from much of the Cook Strait shore as a consequence of some form of seston limitation, most probably low organic matter concentrations.

Future research will focus upon more frequent seston sampling for TPM, POM and PCOM, as well as for particulate $\mathrm{C}$ and $\mathrm{N}$ and chlorophyll a concentrations. This will better address the question of the duration and timing of the availability of seston quantity and quality, and the concomitant duration and timing of periods of net energy loss or gain for all 3 mussel species. It is hoped that this additional information will help to explain the very different bioenergetic re- 
sponses of all 3 mussel species during the summer, when seston conditions at Island Bay and Mahanga Bay were apparently relatively similar. With these additional data, bioenergetics models will be developed to more accurately describe the annual energy balance of each species to confirm whether findings from the present study do explain the unusual absence of mussels from many exposed Cook Strait shores.

Acknowledgements. I thank Robert Williamson, Nicole Bell, Michael Manning and Anjali Pande of Victoria University for technical assistance. Thanks to Dr Len Tong, Manager of NIWA's Aquaculture Facility for permission to work at Mahanga Bay, and to John Illingworth of NIWA for assistance with the seawater supply system. This research was supported by funding from the Internal Grants Committee, the School of Biological Sciences (both of Victoria University of Wellington), and the New Zealand Lottery Grants Board (grant number SR30991); their assistance is greatly appreciated.

\section{LITERATURE CITED}

Bayne BL, Hawkins AJS (1990) Filter feeding in bivalve molluscs. In: Mellinger J (ed) Animal nutrition and transport processes, Vol 1. Nutrition in wild and domestic animals. Karger, Basel, p 70-83

Bayne BL, Newell RC (1983) Physiological energetics of marine molluscs. In: Saleuddin ASM, Wilbur KM (eds) The Mollusca, Vol 4, Physiology, Part 1. Academic Press, New York, p 407-515

Bayne BL, Widdows J (1978) The physiological ecology of two populations of Mytilus edulis L. Oecologia (Berlin) 37 : $137-162$

Bayne BL, Worrall CM (1980) Growth and production of mussels, Mytilus edulis, from two populations. Mar Ecol Prog Ser 3:317-328

Bayne BL. Thompson RJ, Widdows J (1973) Some effects of temperature and food on the rate of oxygen consumption by Mytilus edulis L. In: Wieser W (ed) Effects of temperature on ectothermic organisms. Springer-Verlag, Berlin, p 181-193

Bayne BL, Widdows J, Thompson RJ (1976) Physiological integrations. In: Bayne BL (ed) Marine mussels. Cambridge University Press, Cambridge, p 261-291

Bayne BL, Hawkins AJS, Navarro E (1987) Feeding and digestion by the common mussel Mytilus edulis L. (Bivalvia: Mollusca) in mixtures of silt and algal cells at low concentrations. J Exp Mar Biol Ecol 111:1-22

Booth JD (1975) Seasonal and tidal variations in the hydrology of Wellington harbour. NZ J Mar Freshw Res 9: 333-354

Bowman MJ, Kibblewhite AC, Chiswell SM, Murtagh RA (1983) Circulation and mixing in greater Cook Strait, New Zealand. Oceanol Acta 6:383-391

Bricelj VM. Malouf RE (1984) Influence of algal and suspended sediment concentrations on the feeding physiology of the hard clam Mercenaria mercenaria. Mar Biol $84: 155-165$

Brodie JW (1958) A note on tidal circulation in Port Nicholson. New Zealand. NZ J Geol Geophys 1:684-702
Conover RJ (1966) Assimilation of organic matter by zooplankton. Limnol Oceanogr 11:338-354

Conover WR, Iman RI (1981) Rank transformations as a bridge between parametric and nonparametric statistics. Am Stat 35:124-129

Crisp DJ (1971) Energy flow measurements. In: Holm NA, McInytre AD (eds) Methods for the study of marine benthos, IBP Handbook No. 16. Blackwell Scientific Publications, Oxford, p 197-279

Dame RF (1976) Energy flow in an intertidal oyster population. Estuar Coast Mar Sci 4:243-253

Gnaiger E (1983) Calculation of energetic and biochemical equivalents of respiratory oxygen consumption. In Gnaiger E, Forstner $\mathrm{H}$ (eds) Polargraphic oxygen sensors: aquatic and physiological applications, Appendix C Springer, New York, p 337-345

Griffiths CL, King JA (1979) Some relationships between size, food availability and energy balance in the ribbed mussel Aulacomya ater. Mar Biol 51:141-149

Griffiths RJ (1980) Natural food availability and assimilation in the bivalve Choromytilus meridionalis. Mar Ecol Prog Ser 3:151-156

Harris TFW (1990) Greater Cook Strait. DSIR (Department of Scientific and Industrial Research) Marine and Freshwater, Wellington, p 212

Hawkins AJS, Bayne BL (1985) Seasonal variation in the balance between physiological mechanisms of feeding and digestion in Mytilus edulis (Bivalvia: Mollusca). Mar Biol 82:233-240

Hawkins AJS, Bayne BL (1992) Physiological interrelations and the regulation of production. In: Gosling $E$ (ed) The mussel Mytilus: ecology, physiology, genetics and culture. Elsevier, Amsterdam, p 171-222

Heath RA (1977) Circulation and hydrology of Wellington Harbour. NZ Oceanogr Inst Summary No. 12:1-8

Labarta U, Fernádez-Reiríz MJ, Babarro JMF (1997) Differences in physiological energetics between intertidal and raft cultivated mussels Mytilus galloprovincialis. Mar Ecol Prog Ser 152:167-173

Maxwell BE (1956) Hydrobiological observations for Wellington Harbour. Trans R Soc NZ 83:493-503

Navarro E, Iglesias JIP, Pérez A, Labarta U, Beiras R (1991) The physiological energetics of mussels (Mytilus galloprovincialis Lmk) from different cultivation rafts in the Ría de Arosa (Galicia, N.W. Spain). Aquaculture 94:197-212

SAS (1987) Statistical analytical systems, user's guide. Cary, $\mathrm{NC}$

Stephenson TA, Stephenson A (1949) The universal features of zonation between tidemarks on rocky coasts. J Ecol $37: 289-305$

Widdows J (1978) Combined effects of body size, food concentration and season on the physiology of Mytilus edulis. J Mar Biol Assoc UK 58:109-124

Widdows J (1985) Physiological procedures. In: Bayne BL and 9 others (eds) The effects of stress and pollution on marine animals. Praegar Scientific, New York, p 161-178

Widdows J, Bayne BL (1971) Temperature acclimation of Mytilus edulis with reference to its energy budget. I Mar Biol Assoc UK 51:827-843

Widdows J, Johnson D (1988) Physiological energetics of Mytilus edulis: Scope for Growth. Mar Ecol Prog Ser 46:113-121

Widdows J, Fieth P, Worrall CM (1979) Relationships between seston, available food and feeding activity in the common mussel Mytilus edulis. Mar Biol 50:195-207

Submitted: July 6, 1999; Accepted: October 13, 1999

Proofs received from author(s): February 21, 2000 